\title{
Experimental observations on the effect of added dispersing agent on phenol biodegradation in a microporous membrane bioreactor
}

\author{
Ruey-Shin Juang ${ }^{\mathrm{a}, *}$, Tsuey-Ping Chung ${ }^{\mathrm{a}}$, Maw-Ling Wang ${ }^{\mathrm{b}}$, Duu-Jong Lee ${ }^{\mathrm{c}}$ \\ a Department of Chemical Engineering and Materials Science, Yuan Ze University, Chung-Li 32003, Taiwan \\ ${ }^{\mathrm{b}}$ Department of Environmental Engineering, Hung Kuang University, Taichung 433, Taiwan \\ ${ }^{\mathrm{c}}$ Department of Chemical Engineering, National Taiwan University, Taipei 106, Taiwan \\ Received 12 April 2007; received in revised form 21 May 2007; accepted 13 June 2007 \\ Available online 17 June 2007
}

\begin{abstract}
The effect of added dispersing agent tetrasodium pyrophosphate (TSP) on the degradation of phenol by Pseudomonas putida BCRC 14365 in a microporous membrane bioreactor was experimentally studied at $30{ }^{\circ} \mathrm{C}$ and $\mathrm{pH}$ 7. The hollow fibers were pre-wetted with ethanol to make them more hydrophilic. Phenol solution was passed through the lumen of the module and the cell medium was flowed across the shell. All Experiments were carried out at a fixed initial cell density of $0.023 \mathrm{~g} / \mathrm{L}$ ( 0.06 optical density). Phenol could be completely degraded with the help of the biofilm formed on the outer surfaces of the fibers even though its level was high up to $3 \mathrm{~g} / \mathrm{L}$. It was also shown that the presence of TSP in cell medium could improve biodegradation. The amount of added TSP was optimized to be $1 \mathrm{~g} / \mathrm{L}$ under the conditions studied. In this situation, $3 \mathrm{~g} / \mathrm{L}$ of phenol could be completely removed within $76 \mathrm{~h}$, much shorter than the absence of TSP (within $92 \mathrm{~h}$ ).
\end{abstract}

(c) 2007 Elsevier B.V. All rights reserved.

Keywords: Biodegradation; Phenol; Microporous membrane bioreactor; Dispersing agent; Biofilm

\section{Introduction}

In the polluted effluents from industrial sources such as petroleum refineries, plastic/coke oven industries, and phenolic resin manufacturing processes, organic chemicals with high levels (up to several grams per liter) are possibly prevalent [1]. To reduce substrate inhibitory effect during biodegradation for such concentrated substrate solutions, it is highly desired to construct a barrier between the substrates and the bacteria. Cells immobilized on microporous hollow fibers to form membrane-attached biofilm can be treated as a so-called microporous membrane bioreactor (MMBR) for biodegradation applications [2-6]. Due to its high surface area per unit module volume, microporous hollow fibers serve as the better immobilization supports than alginate bead, activated carbon, sintered glass, and polymer bead [7]. Moreover, microporous hollow fibers can act as the barriers to avoid mass movement but allow restricted or regulated passage of one or more species through the pores [8]. In

\footnotetext{
* Corresponding author. Tel.: +886 3 4638800x2555; fax: +88634559373.

E-mail address: rsjuang@ce.yzu.edu.tw (R.-S. Juang).
}

practice, cells immobilized on microporous hollow fibers could biodegrade phenol at a level above $1 \mathrm{~g} / \mathrm{L}$ when the substrate solution does not have extremes of $\mathrm{pH}$ and/or high salinity. For instance, $1.5 \mathrm{~g} / \mathrm{L}$ of phenol can be fully removed within $58 \mathrm{~h}$ by Pseudomonas putida (P. putida) ATCC 17484 in cellulose acetate MMBR [3]. Even when the initial phenol concentration increased to $3.5 \mathrm{~g} / \mathrm{L}$, only $250 \mathrm{~h}$ is required for complete degradation by $P$. putida in polysulfone MMBR [4].

As have demonstrated previously, biological treatment of organic compounds in such MMBR is caused by a combination of suspended (existing in the bulk flow of the module) and immobilized cells (existing in the membrane-attached biofilm) [5,6]. Hence, the thickness of the biofilm would play a crucial role in this subject. Although, the membrane fouling reducers such as cationic water-soluble polymers have been used in submerged membrane bioreactors to enhance the flux [9], tetrasodium pyrophosphate (TSP) is one of the commonly used dispersing (i.e., sequestering) agents that retard the attachment of bacteria in microbiological $[2,6,10,11]$ and geochemical applications [12]. For the biodegradation experiments occurring in MMBR, however, the dosage of dispersing agent TSP remains highly inconsistent. For example, Aziz et al. [2] have added 


\begin{tabular}{|c|c|}
\hline \multicolumn{2}{|c|}{ Nomenclature } \\
\hline BDS & biofilm degradation stage \\
\hline CDS & $\begin{array}{l}\text { combined (biofilm and suspension) degradation } \\
\text { stage }\end{array}$ \\
\hline$S$ & $\begin{array}{l}\text { substrate (phenol) level at any time in the solution } \\
(\mathrm{mg} / \mathrm{L})\end{array}$ \\
\hline$t$ & reaction time $(\mathrm{h})$ \\
\hline$v$ & degradation rate defined in Eq. (2) (mg/(L h)) \\
\hline$X$ & cell concentration (OD at $600 \mathrm{~nm})$ \\
\hline \multicolumn{2}{|c|}{ Greek letter } \\
\hline$\mu$ & specific cell growth rate defined in Eq. (1) $\left(\mathrm{h}^{-1}\right)$ \\
\hline
\end{tabular}

$10 \mathrm{~g} / \mathrm{L}$ TSP to protect against biofouling of the fibers in the biodegradation of trichloroethylene by Methylosinus trichosporium $\mathrm{OB} 3 \mathrm{~b}$ in polypropylene $\mathrm{MMBR}$ (fiber pore size $0.05 \mu \mathrm{m}$, area $1.0 \mathrm{~m}^{2}$ ). On the other hand, Chung et al. [6] have added a relatively smaller amount of TSP $(1 \mathrm{~g} / \mathrm{L})$ for this purpose in the biodegradation of phenol by $P$. putida in polypropylene MMBR (fiber pore size $0.2 \mu \mathrm{m}$, area $0.02 \mathrm{~m}^{2}$ ).

The aim of this work was to systematically examine the effect of the amount of added dispersing agent TSP on the overall biodegradation performance. The degradation of phenol by $P$. putida BCRC (Bioresource Collection Research Center) 14365 in polypropylene MMBR was exemplified because phenol is a popular and potential pollutant in industrial effluents. In addition, we proposed a more definite way to distinguish the respective role of biofilm and suspended cells on phenol degradation in such a MMBR.

\section{Materials and methods}

\subsection{Microorganism, nutrient medium, and solutions}

P. putida BCRC 14365 used in this work was obtained from the Food Industry Research and Development Institute, Hsinchu, Taiwan. The stock cultures were stored at $4{ }^{\circ} \mathrm{C}$. The nutrient medium (NB) contained $3 \mathrm{~g} / \mathrm{L}$ of beef extract, $5 \mathrm{~g} / \mathrm{L}$ of peptone, and mineral salt medium (MSM) at $\mathrm{pH}$ 7. The composition of MSM in g/L was $\mathrm{KH}_{2} \mathrm{PO}_{4}(0.42), \mathrm{K}_{2} \mathrm{HPO}_{4}(0.375),\left(\mathrm{NH}_{4}\right)_{2} \mathrm{SO}_{4}$ (0.244), $\mathrm{NaCl}(0.015), \mathrm{CaCl}_{2} \cdot 2 \mathrm{H}_{2} \mathrm{O}(0.015), \mathrm{MgSO}_{4} \cdot 7 \mathrm{H}_{2} \mathrm{O}$ (0.05), and $\mathrm{FeCl}_{3} \cdot 6 \mathrm{H}_{2} \mathrm{O}$ (0.054). A phosphate buffer ( $\left.\mathrm{pH} 7\right)$ was prepared by dissolving $8 \mathrm{~g} / \mathrm{L} \mathrm{NaCl}, 0.2 \mathrm{~g} / \mathrm{L} \mathrm{KCl}, 1.15 \mathrm{~g} / \mathrm{L}$ $\mathrm{K}_{2} \mathrm{HPO}_{4}$, and $0.2 \mathrm{~g} / \mathrm{L} \mathrm{KH}_{2} \mathrm{PO}_{4}$ in deionized water (Millipore, Milli-Q). Prior to use, the MSM and phosphate buffer were sterilized in autoclave at $121^{\circ} \mathrm{C}$ for $15 \mathrm{~min}$. All inorganic chemicals were offered from Merck Co. as analytical reagent grade.

The substrate solution was prepared by dissolving phenol in the MSM to the desired level (0.1-3 g/L). Different amounts of TSP (tetrasodium pyrophosphate, RDH Co.) were added in both substrate solution and cell medium to investigate its effect during the biodegradation process [2]. The $\mathrm{pH}$ of phenol solution was as prepared in the range 6.5-6.8 without further adjustment, but the $\mathrm{pH}$ of cell medium was adjusted to be 7.0 by adding a small amount of $0.1 \mathrm{M} \mathrm{HCl}$.

\subsection{Free suspension cultivation}

P. putida cells were activated at $30^{\circ} \mathrm{C}$ in the $\mathrm{NB}$, into which $0.1 \mathrm{~g} / \mathrm{L}$ of phenol was added for enzyme adaptation for $24 \mathrm{~h}$. Activated cells in the late-exponential phase were harvested as inoculums. The cells collected after centrifugation (6000 rpm) for $10 \mathrm{~min}$ were suspended in phosphate buffer and re-centrifuged. After cleaning, the activated cells were inoculated into the culture medium $(250 \mathrm{~mL})$ in $500-\mathrm{mL}$ Erlenmeyer flasks to give a cell concentration of about $1.2 \times 10^{8}$ cells $/ \mathrm{mL}$. This corresponds to an optical density (OD) of 0.06 at $600 \mathrm{~nm}$ or a dried cell weight of $0.023 \mathrm{~g} / \mathrm{L}$. After inoculation, the flask was capped with the cotton plugs and placed in a shaker controlled at $120 \mathrm{rpm}$ and $30^{\circ} \mathrm{C}$.

The number of colonies and dry cell weight were determined as follows. Serial dilutions of the culture were conducted and $0.1 \mathrm{~mL}$ of the diluted culture was spread on a plate. The plate was then incubated at $30^{\circ} \mathrm{C}$ for $24 \mathrm{~h}$ and the number of colonies was counted. In separate experiments, cells in the cultures $(40 \mathrm{~mL})$ with different concentrations were harvested by centrifugation (6000 rpm) at $4{ }^{\circ} \mathrm{C}$ for $10 \mathrm{~min}$ several times and washed with deionized water. The cells were subsequently dried at $60^{\circ} \mathrm{C}$ over $24 \mathrm{~h}$ until a constant weight was obtained.

\subsection{MMBR and the related experiments}

The microporous hollow fiber module used was manufactured by Microdyn Co., Wuppertal, Germany (LM 2P18). It consists of $16 \mathrm{PP}$ fibers (pore size $0.2 \mu \mathrm{m}$ ) encased in a cylindrical shell in an analogous manner to the shell-and-tube heat exchanger. The detailed properties of the module were reported earlier [6]. The micropores of the PP fibers are basically hydrophobic, and become more hydrophilic after they are prewetted by circulating ethanol for $6 \mathrm{~h}$ throughout the module [13]. The module was then washed with deionized water for $6 \mathrm{~h}$ before use. Fig. 1 shows a schematic diagram of the experimental setup.

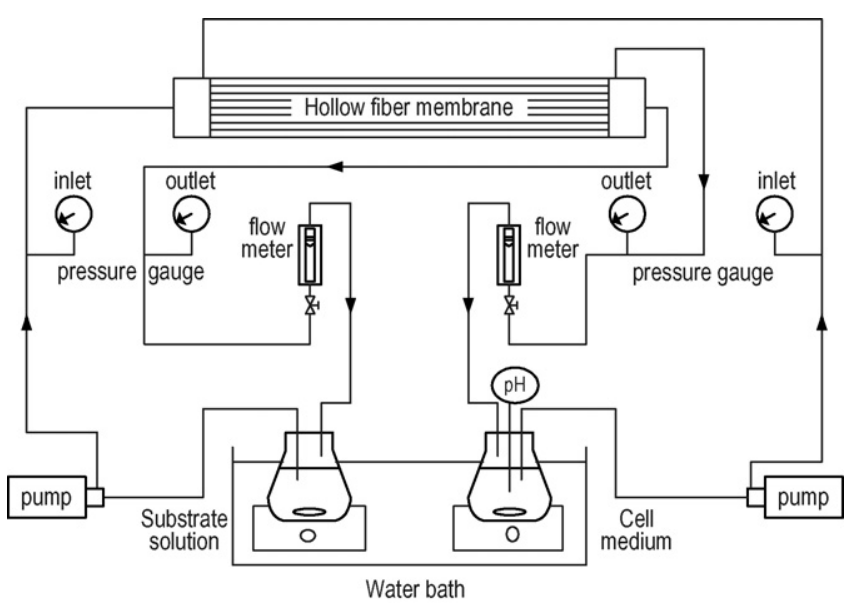

Fig. 1. Schematic diagram of the experimental setup for the biodegradation of phenol in MMBR. 
After the activated cells were inoculated in culture medium to a concentration of $0.023 \mathrm{~g} / \mathrm{L}$, they were pumped across the shell of the module at $2.0 \mathrm{~mL} / \mathrm{min}$ using a peristaltic pump (ColeParmer, Masterflex 7518-00). The substrate solution was flowed through the lumen at $2.4 \mathrm{~mL} / \mathrm{min}$. Substrate solution and cell medium were circulated in the MMBR and totally recycled to each external flask. The total volume of each solution in the external flask, tubing, and the corresponding side of the module (i.e., working volume) was $350 \mathrm{~mL}$ in all experiments. Both external flasks were agitated by magnetic stirrers to provide the required aeration, and the temperature was fixed at $30^{\circ} \mathrm{C}$ in water bath. Samples $(1 \mathrm{~mL})$ were taken from the two external flasks at regular intervals $(1-5 \mathrm{~h})$.

\subsection{Post-treatment of the microporous hollow fiber module}

To prevent possible contamination of the medium in the followed experiments, the MMBR used was immediately sterilized and cleaned after biodegradation tests. Firstly, it was flushed with $70 \%$ ethanol and deionized water for $1 \mathrm{~h}$ each at higher flow rates (lumen $5.6 \mathrm{~mL} / \mathrm{min}$, shell $5.0 \mathrm{~mL} / \mathrm{min}$ ). The module was then washed with a $0.5 \%$ (w/v) enzymatic solution of TergA-Zyme (Alconox Inc., USA) in order at the above-mentioned high flow rates for $1 \mathrm{~h}$ and at the common flow rates (lumen $2.4 \mathrm{~mL} / \mathrm{min}$, shell $2.0 \mathrm{~mL} / \mathrm{min}$ ) for $3 \mathrm{~h}$. After washing, the former solution becomes yellow and the latter solution is colorless. Finally, the hollow fiber module was rinsed in sequence with deionized water, $0.5 \mathrm{M} \mathrm{NaOH}$, and $0.1 \mathrm{M} \mathrm{NaOH}$ for $0.5 \mathrm{~h}$ each at high flow rates.

\subsection{Analysis of cells and phenol}

Cell concentration was determined by measuring the OD with an UV/visible spectrophotometer (Jasco UV-550, Japan) and 1$\mathrm{cm}$ path length square quartz cuvette with culture medium as reference. Samples were subject to filtration through a Millipore filter $(0.2 \mu \mathrm{m})$ before HPLC analysis of phenol on a Phenomenex C18 column (particle size, $5 \mu \mathrm{m}$ ). A mixture of methanol $(60 \%$, $\mathrm{v} / \mathrm{v}$ ) and water was used as the mobile phase, which flowed at $1.0 \mathrm{~mL} / \mathrm{min}$. An aliquot of the sample $(10 \mu \mathrm{L})$ was injected and was analyzed using the UV detector (Jasco 975, Japan). The wavelength for phenol was $280 \mathrm{~nm}$. Each experiment was duplicated under identical conditions. The reproducibility of the concentration measurements is mostly within $5 \%$.

\section{Results and discussion}

\subsection{Typical biodegradation results in MMBR}

Fig. 2 shows the time profiles of cell growth and biodegradation of $0.5 \mathrm{~g} / \mathrm{L}$ of phenol in MMBR. In this figure and hereinafter, phenol levels in both lumen and shell of the module, and their sum (the total level), are shown separately. It is found that the biomass exhibits a typical batch growth curve of a microbial culture that is divided into the lag, exponential, stationary, and death phases. The lag phase extends about $9 \mathrm{~h}$ where there is no appreciable cell growth but somewhat decreases. A sharp

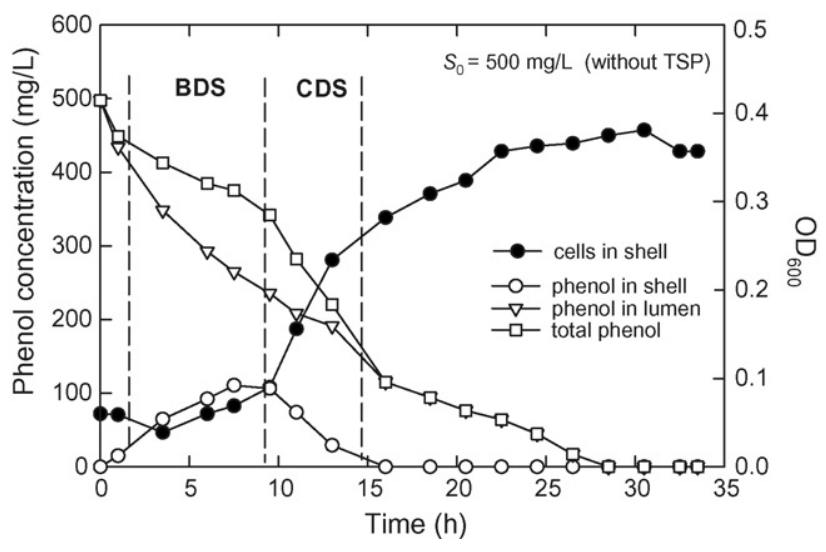

Fig. 2. Time profiles of cell growth and phenol biodegradation in MMBR in the absence of TSP (BDS locates before the end of the lag phase of shell-side suspended cells, whereas CDS starts with the exponential phase).

drop of the total phenol level (around 10\%) occurs at the first $1 \mathrm{~h}$ with a slow decline of cell density. This is understood as a result of the sorption of phenol on the surface of the fibers [6]. After the lag phase, the biomass begins to grow quickly at the fast expense of phenol degradation. The highest suspended cell density is $0.381 \mathrm{OD}$ (specific growth rate, $\mu=0.11 \mathrm{~h}^{-1}$ ), and phenol is completely degraded within $28 \mathrm{~h}$ (degradation rate, $v=25.0 \mathrm{mg} /(\mathrm{Lh}))$. The specific cell growth rate $\mu$ and phenol degradation rate $v$ in a batch system is defined as [14].

$\mu=\frac{1}{X} \frac{\mathrm{d} X}{\mathrm{~d} t}=\frac{\mathrm{d}(\ln X)}{\mathrm{d} t}$

$v=\frac{\mathrm{d} S}{\mathrm{~d} t}$

where $X$ is the cell concentration in OD at $600 \mathrm{~nm}$ and $S$ is the phenol level in $\mathrm{mg} / \mathrm{L}$. The value of $\mu$ is determined at the exponential phase of the growth curve.

On the other hand, there is no cell growth in the lumen during the degradation process. This means that the fibers with a pore size of $0.2 \mu \mathrm{m}$ can restrict the penetration of $P$. putida whose size is about $0.5 \mu \mathrm{m}$ [6]. Phenol level in the lumen continuously reduces to zero; however, it increases initially in the shell and reaches the maximum near when the exponential phase of cell growth starts. It is interesting to note that when phenol level in the shell reduces to zero, about $0.12 \mathrm{~g} / \mathrm{L}$ of phenol is still present in the lumen with 0.28 -OD cells.

According to batch suspension experiments [15], the $\mu$ value for $P$. putida on phenol reaches maximum at a substrate level of $0.12 \mathrm{~g} / \mathrm{L}$. Beyond that level, substrate inhibitory effect occurs. At a phenol level of $0.4 \mathrm{~g} / \mathrm{L}$, for example, the $\mu$ value decreases to $73 \%$ of its maximum. Within the first $9 \mathrm{~h}$ in MMBR, however, phenol is continuously degraded but no suspended cells are detected in the bulk flows of both sides. In order to avoid substrate inhibitory effect, cells are attached or adhered to the outer surfaces of the fibers to form immobilized biofilm. It was experimentally found that the color of fiber surface changes from initially white to light yellow, and eventually deep yellow. After 9-h operation, biomass eventually adapts the environments and starts to grow in the bulk flow of the shell side; at this time the 

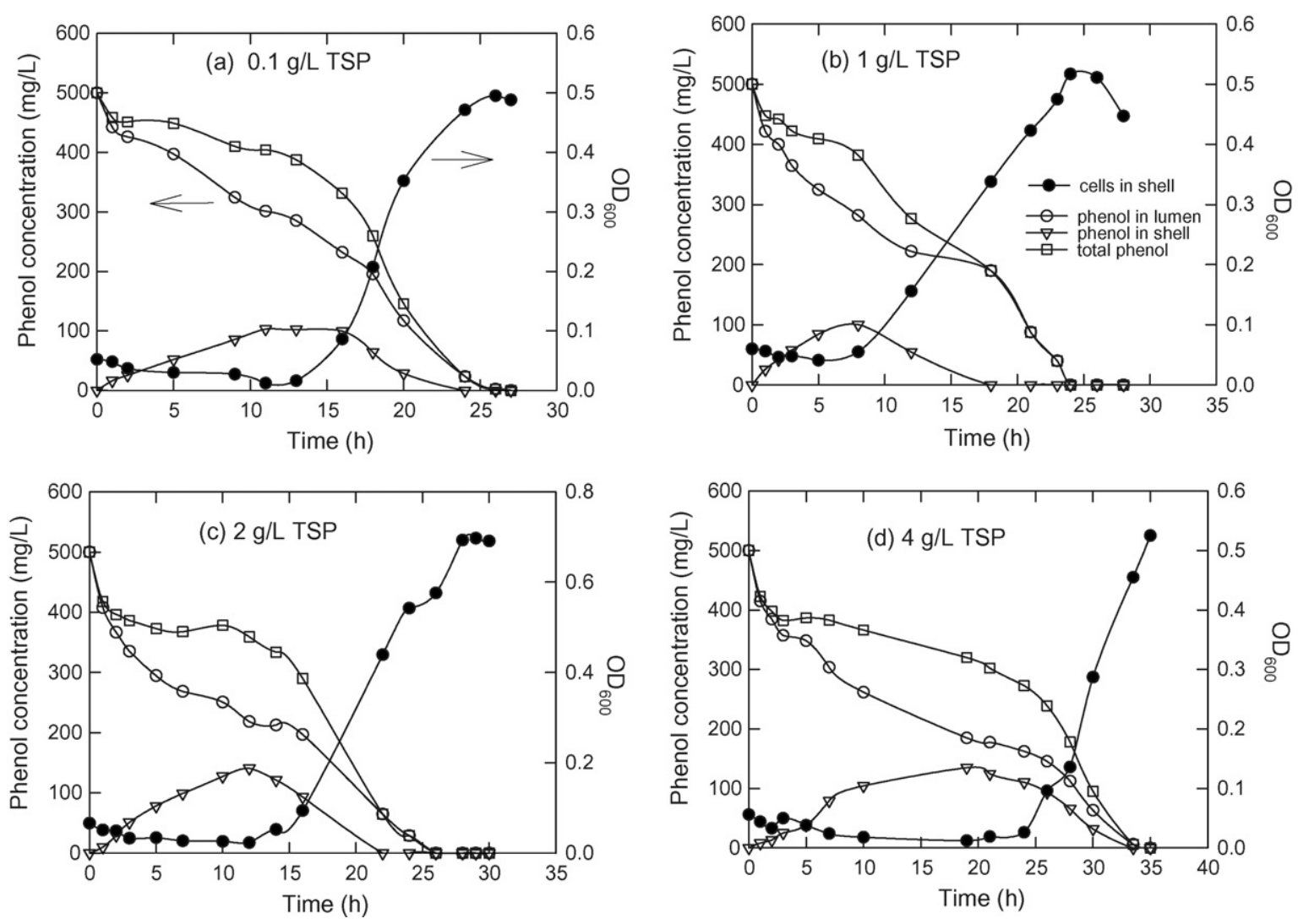

Fig. 3. Time profiles of cell growth and phenol biodegradation at different concentrations of TSP.

total phenol level becomes $0.35 \mathrm{~g} / \mathrm{L}$. In other words, the presence of membrane-attached biofilm on the outer surface of the fibers could significantly improve the tolerance limit for concentrated substrate solutions [16,17].

In this regard, we would like to divide the whole biodegradation process in MMBR into two stages, as shown in Fig. 2. The first is the biofilm degradation stage (BDS), which locates before the end of the lag phase of shell-side suspended cells. The followed stage is the combined degradation stage (CDS) due to the biofilm and suspended cells, which starts with the exponential phase of shell-side suspended cells. Evidently, the degradation rate of phenol in CDS is larger than that in BDS. This is because the degradation of organic compounds by suspended cells is generally faster than that by immobilized cells although the immobilized cells have higher tolerance limit [15].

\subsection{Effect of the added amount of TSP}

Biofilm fouling is a common problem encountered in industrial wastewater treatment systems. Previous authors have indicated that the thicker biofilm results in decreased membrane bioreactor performance due to diffusion limitations [18]. The prevention of biofilm formation is difficult because of the high potential of attachment and adhesion mechanisms of the cells, and thus control strategies are needed [19]. For example, the use of high liquid-phase velocity and air scour to shear biomass off the membranes is a common strategy. On the other hand,
Aziz et al. [2] have used TSP as a dispersing agent to retard the attachment of bacteria and to protect against biofouling of the membranes. Here, experiments were conducted by adding 0.1 , 1,2 , and $4 \mathrm{~g} / \mathrm{L}$ of TSP to the cell medium to examine the effect of biofilm formation on phenol biodegradation and cell growth at an initial phenol level of $0.5 \mathrm{~g} / \mathrm{L}$ (Fig. 3). It was experimentally found that the presence of TSP in phenol solution does not apparently affect the sorption of phenol on the surface of the fibers when cells are not absent (not shown). This is not the case in the presence of cells (Fig. 3) for higher TSP concentrations (2 and $4 \mathrm{~g} / \mathrm{L}$ ) where the total phenol level decreases by $20 \%$ instead of $10 \%$ for lower TSP concentrations.

It is found that the time required for complete degradation is shortened and the suspended cells increase when the amount of TSP increases from 0 to $1 \mathrm{~g} / \mathrm{L}$. The maximum cell densities are $0.38,0.49$, and $0.52 \mathrm{OD}$ when $0,0.1$, and $1 \mathrm{~g} / \mathrm{L}$ of TSP are present in cell medium, respectively. However, more TSP $(2-4 \mathrm{~g} / \mathrm{L})$ does not considerably improve the degradation performance (Figs. 3c and d). For example, the maximum cell density closes to 0.53 OD when $4 \mathrm{~g} / \mathrm{L}$ of TSP is added. TSP is one kind of coagulant in nature that may cause cell dissociation at its higher dosages. It is believed that biofilm contains a continuous, gel-like matrix in which the cells are embedded. Characklis [16] has described four stages of biofilm development, i.e., surface contact by mass transfer, cell adherence, biofilm growth and biofilm stripping. The organics and bacteria contact with substratum surface by mass transfer. These organic compounds adhere on the surface and form a conditioning film, which is suitable for cell growth. 


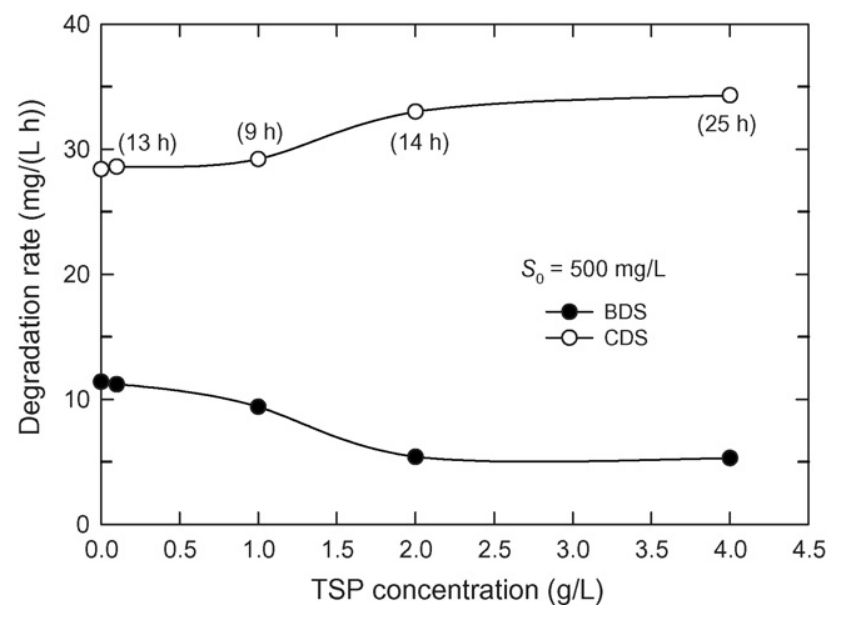

Fig. 4. Effect of added TSP concentration on the biodegradation rate of phenol in MMBR (The value in the parentheses indicates the time required to reach the CDS).

Bacteria adhere and grow on the surface-forming biofilm. When biofilm increases in thickness, it strips the covering from the surface by shear stress of the fluid or by gravity of cells themselves [17]. A significant increase of suspended cell density in the exponential phase could partially result from the stripped biofilm as shown in Fig. 3.

Fig. 4 shows the effect of the amount of added TSP on phenol degradation rate in BDS and CDS. It is evident that phenol degradation rate decreases in BDS and increases in CDS with increasing amount of TSP. In the degradation of phenol by $P$. putida ATCC 17484 in polysulfone MMBR, Loh et al. [4] have also found that cells diffuse through the membrane-attached biofilm when phenol reaches no inhibitory level in a few tests. In their case, the time taken for complete degradation with cell diffusion is shorter because suspended cells are responsible for rapid phenol degradation.

Considering the time required to start CDS (the value in the parentheses as shown in Fig. 4), we select $1 \mathrm{~g} / \mathrm{L}$ of TSP for further studies. In fact, this exactly reflects the effect of the amount of TSP on the lag phase according to the definition of CDS. It is expected that biofilm thickness decrease with increasing the amount of TSP. At lower TSP concentrations, the thinner biofilm allows a smaller level of phenol to be transferred to the cell medium; so the lag phase of cell growth is longer. On the other hand, a larger level of phenol reaches to the cell medium at higher TSP concentrations; however, the sufficiently high amount of TSP may be toxic to the cells (e.g., causing cell dissociation) [5,6]. The optimal biofilm thickness (or TSP concentration) will be determined by compensating mass transfer effect and the relative contribution of biofilm and suspended cells in phenol degradation and cell growth. In the present MMBR, $1 \mathrm{~g} / \mathrm{L}$ of TSP could presumably keep appropriate biofilm thickness in company with more cells in suspension, leading to better biodegradation performance.
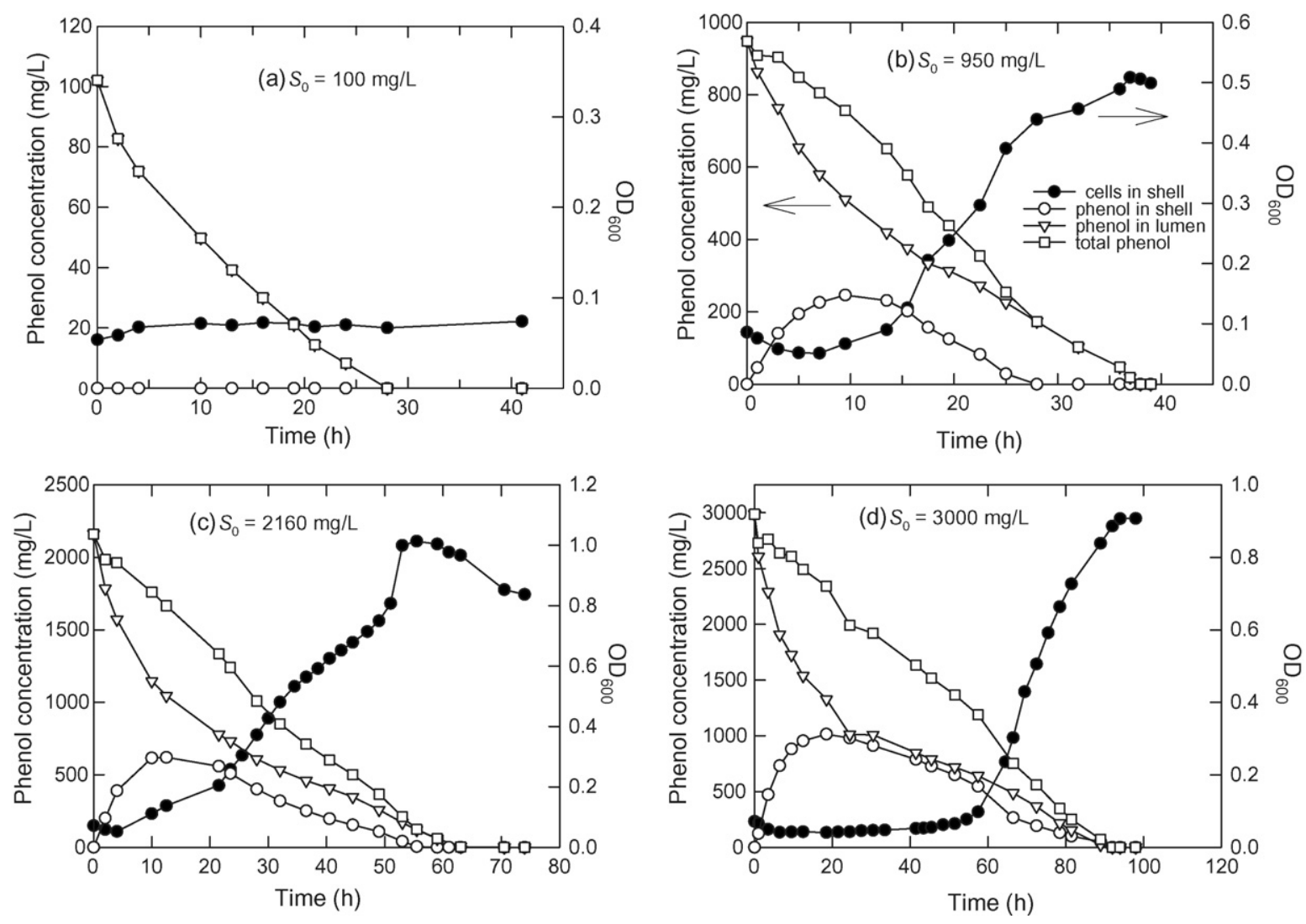

Fig. 5. Time profiles of cell growth and phenol biodegradation at different initial phenol levels in MMBR in the absence of TSP. 

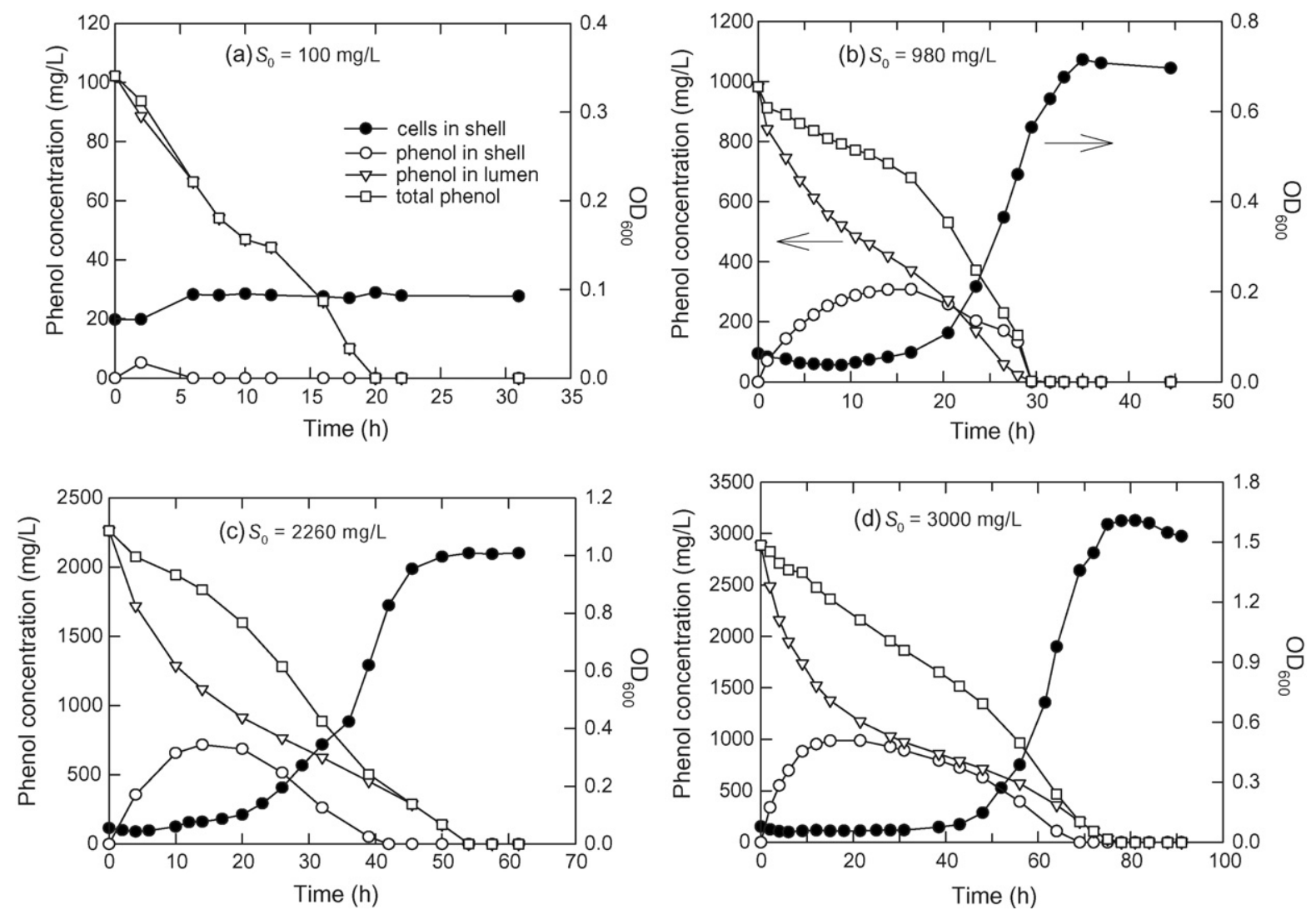

Fig. 6. Time profiles of cell growth and phenol biodegradation at different initial phenol levels in MMBR with $1 \mathrm{~g} / \mathrm{L}$ of TSP.

\subsection{Effect of the initial phenol level}

The effects of initial phenol level on cell growth and phenol biodegradation in MHF module, without and with TSP $(1 \mathrm{~g} / \mathrm{L})$, are shown in Figs. 5 and 6, respectively. It is evident that the addition of TSP leads to increase the maximum suspended cell density under comparable conditions and to shorten the time required for complete removal of phenol. In the absence of TSP, the maximum cell density is $1.01 \mathrm{OD}$ at an initial phenol level of $2.2 \mathrm{~g} / \mathrm{L}$, and complete degradation of $3 \mathrm{~g} / \mathrm{L}$ of phenol is achieved within $92 \mathrm{~h}$. However, the maximum cell density becomes 1.67 $\mathrm{OD}$ at an initial phenol level of $3 \mathrm{~g} / \mathrm{L}$ in the presence of $1 \mathrm{~g} / \mathrm{L}$ of TSP. Complete biodegradation of $3 \mathrm{~g} / \mathrm{L}$ phenol is achieved within $76 \mathrm{~h}$, which is much faster than the TSP-free results $(92 \mathrm{~h}$ for $3 \mathrm{~g} / \mathrm{L}$ phenol).

Fig. 7 compares the influence of initial phenol level on the degradation rate of phenol in BDS and CDS, without and with TSP. As expected, CDS exhibits better biodegradation efficiency than BDS, particularly in the presence of TSP (Fig. 7b). At an initial phenol level of $2.2 \mathrm{~g} / \mathrm{L}$, e.g., the degradation rate is $35.6 \mathrm{mg} /(\mathrm{Lh})$ in BDS and $36.4 \mathrm{mg} /(\mathrm{Lh})$ in CDS when the cell medium is free of TSP, whereas it becomes $34.9 \mathrm{mg} /(\mathrm{Lh})$ in BDS and $53.0 \mathrm{mg} /(\mathrm{Lh})$ in CDS when $1 \mathrm{~g} / \mathrm{L}$ of TSP is added. The CDS exhibits outstanding biodegradation performance $(>50.0 \mathrm{mg} /(\mathrm{Lh}))$ when phenol level is larger than $1 \mathrm{~g} / \mathrm{L}$. At such high substrate levels, it is believed that biofouling (i.e., the clogging of pores) is the most important limitation for mass transfer and biodegradation in MMBR.
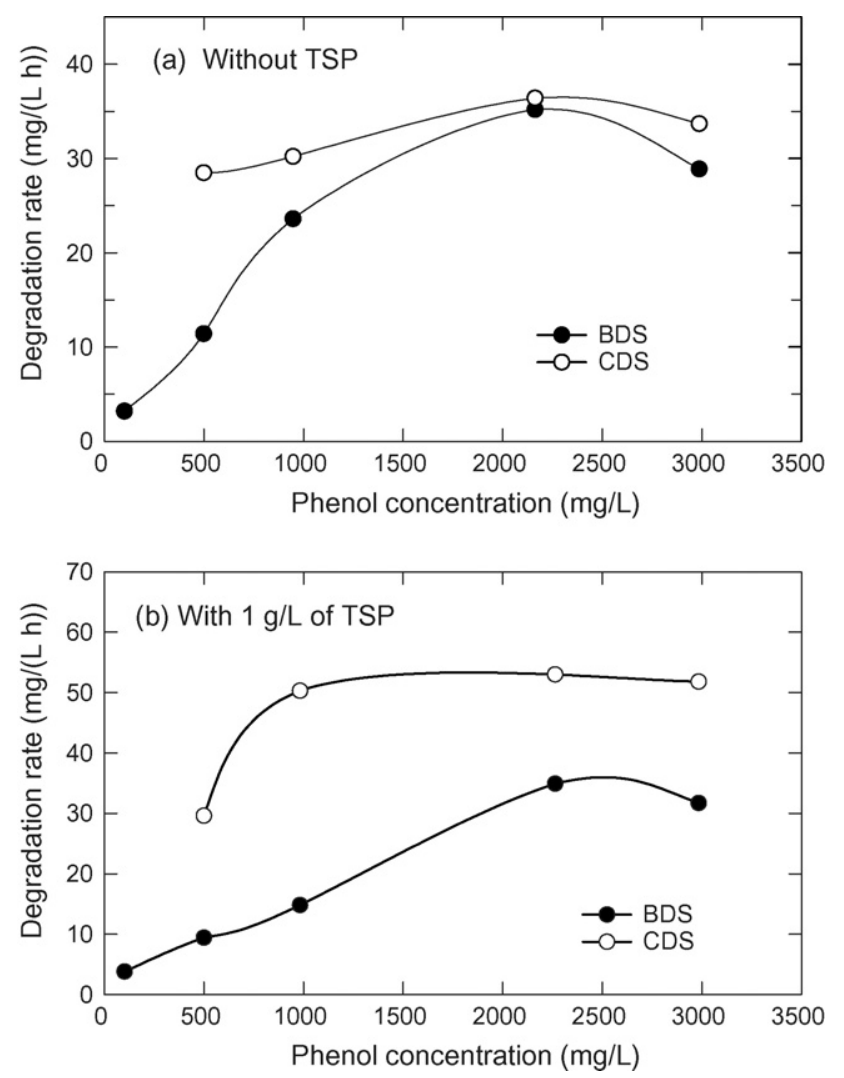

Fig. 7. Effect of initial phenol level on the biodegradation rate of phenol in MMBR. 
On the other hand, solution even containing a phenol level up to $3 \mathrm{~g} / \mathrm{L}$ can be readily treated in MMBR regardless of the presence or absence of dispersing agents. The enhancement of toxicity tolerance is an important characteristic of cell immobilization [8], likely due to the formation of cell colonies onto the supports. The close cell-to-cell contact affects the dynamics of cell membrane and increases cell's tolerance to xenobiotics. The MMBR can be applied to treat highly polluted waters in a cyclic batch fashion; no dilution of toxic wastewater is required [3-6,17]. Therefore, remediation of the contaminated waters would be the potentially attractive application of such bioreactor, particularly for salt-free solutions.

\section{Conclusions}

A polypropylene microporous hollow fiber module was used as a bioreactor to degrade phenol in the solution of $\mathrm{pH} 7.0$ by $P$. putida BCRC14365 at $30^{\circ} \mathrm{C}$. Cells were adhered to the surface of the fibers to form attached biofilm to avoid the inhibitory effect for phenol up to $3 \mathrm{~g} / \mathrm{L}$. Two successive stages, biofilm degradation stage and combined degradation stage, could be clearly identified during the whole process. It was observed that the degradation rate of phenol in CDS was larger than that in BDS, irrespective of the absence or presence of a dispersing agent tetrasodium pyrophosphate. Adequate control of the membraneattached biofilm thickness via the addition of TSP could considerably increase the suspended cell density and thus decrease the time required for complete degradation of phenol (because the suspended cells exhibited faster degradation than that the immobilized cells). This is especially the case at higher initial substrate levels $(>1 \mathrm{~g} / \mathrm{L})$, because in this situation biofouling would be the most important limitation for biodegradation in such microporous membrane bioreactor. The optimal amount of added TSP in the cell medium was determined to be around $1 \mathrm{~g} / \mathrm{L}$.

\section{Acknowledgement}

Financial support for this work by the National Science Council, ROC, under Grant NSC94-2218-E-241-001 is gratefully appreciated.

\section{References}

[1] R.L. Autenrieth, J.S. Bonner, A. Akgerman, E.M. McCreary, Biodegradation of phenolic wastes, J. Hazard. Mater. 28 (1991) 29-53.
[2] C.E. Aziz, M.W. Fitch, L.K. Linquist, J.G. Pressman, G. Georgiou, G.E. Speitel, Methanotrophic biodegradation of trichlroethylene in a hollow fiber membrane bioreactor, Environ. Sci. Technol. 29 (1995) 2574 2583.

[3] G. Zhu, T.S. Chung, K.C. Loh, Activated carbon-filled cellulose acetate hollow fiber membrane for cell immobilization and phenol degradation, J. Appl. Polym. Sci. 76 (2000) 695-707.

[4] K.C. Loh, T.S. Chung, W.F. Ang, Immobilized-cell membrane bioreactor for high-strength phenol wastewater, J. Environ. Eng. ASCE 126 (2000) 75-79.

[5] T.P. Chung, P.C. Wu, R.S. Juang, Process development for the degradation of phenol by Pseudomonas putida in hollow fiber membrane bioreactors, Biotechnol. Bioeng. 87 (2004) 219-227.

[6] T.P. Chung, P.C. Wu, R.S. Juang, Use of microporous hollow fibers for improved biodegradation of high-strength phenol solutions, J. Membr. Sci. 258 (2005) 55-63.

[7] S.F. Karel, S.B. Libichi, C.R. Robertson, The immobilization of whole cells: engineering principles, Chem. Eng. Sci. 40 (1985) 1321-1354.

[8] A. Gabelman, S.T. Hwang, Hollow fiber membrane contactors, J. Membr. Sci. 159 (1999) 61-106.

[9] W.N. Lee, I.S. Chang, B.K. Hwang, P.K. Park, C.H. Lee, X. Huang, Changes in biofilm architecture with addition of membrane fouling reducer in a membrane bioreactor, Process Biochem. 42 (2007) 655-661.

[10] A.L.S. Furtado, P. Casper, Different methods for extracting bacteria from freshwater sediment and a simple method to measure bacterial production in sediment samples, J. Microbiol. Methods 41 (2000) 249 257.

[11] J. Pendas, A.O. Vila, C. Rodriguez-Flores, T. Moreiras, J. Figueruelo, F. Molina, Osmotic conditions in rheologic properties of erytrocites, Colloids Surfaces A: Physicochem, Eng. Aspects 195 (2001) 259-262.

[12] J. Yuan, W.L. Garforth, R.J. Pruett, Influence of dispersants on the solubility of calcined kaolin, Appl. Clay Sci. 13 (1998) 137-147.

[13] D. Hadjiev, D. Dimitrov, M. Martinov, O. Sire, Enhancement of the biofilm formation on polymeric supports by surface conditioning, Enzyme Microb. Technol. 40 (2007) 840-848.

[14] A. Kumar, S. Kumar, S. Kumar, Biodegradation kinetics of phenol and catechol using Pseudomonas putida MTCC 1194, Biochem. Eng. J. 22 (2005) 151-159.

[15] T.P. Chung, H.Y. Tseng, R.S. Juang, Mass transfer and intermediate detection for phenol degradation in immobilized Pseudomonas putida systems, Process Biochem. 38 (2003) 1497-1507.

[16] W.G. Characklis, Fouling biofilm development: a process analysis, Biotechnol. Bioeng. 23 (1981) 1923-1960.

[17] P.L. Bishop, T.C. Zhang, Y.C. Fu, Effect of biofilm structure, microbial distributions and mass transport on biodegradation processes, Water Sci. Technol. 31 (1) (1995) 143-152.

[18] L.M.F. dos Santos, A.G. Livingstone, Membrane-attached biofilms for VOC wastewater treatment II: effect of biofilm thickness on performance, Biotechnol. Bioeng. 47 (1995) 90-95.

[19] M. Pasmore, P.M. Todd, B. Pfiefer, M. Rhodes, C.N. Bowman, Effect of polymer surface properties on the reversibility of attachment of Pseudomonas aeruginosa in the early stages of biofilm development, Biofouling 18 (2002) 65-71. 